\title{
Understanding Role of Private Sector in the Development of School Education in Pakistan
}

\author{
Dr. Nasim Qaisrani \\ Professor, Iqra University, Gulshan Campus, Abid Town, Karachi, Pakistan
}

\begin{abstract}
Shahid Hussain Mughal (Corresponding Author)
Assistant Professor, Sukkur Institute of Business Administration (IBA), Air Port Road, Sukkur, Pakistan

Email: smughal38@yahoo.com
\end{abstract}

Ghulam Mohuyuddin Solangi

Ph.D Scholar, Iqra University, Karachi, Pakistan

Email: ghulammuhiyuddin@yahoo.com

Sumaira Faiz

Ph.D Scholar, Iqra University, Gulshan Campus, Abid Town

Karachi, Pakistan

Email: faiz_sumaira@yahoo.com

Abdul Qadeer Soomro

Ph.D Scholar, Iqra University, Gulshan Campus, Abid Town

Karachi, Pakistan

Email: aqs_per@yahoo.com

Accepted: November 12, 2011 Published: December 23, 2011

Doi:10.5296/ijld.v1i2.1189ＵRL: http://dx.doi.org/10.5296/ijld.v1i2.1189

\begin{abstract}
Successive governments in Pakistan responded differently to the role of private sector in the educational development of this country. From 1947 till 1971, private sector was very much active in the promotion of education in the country. But it was also criticized on several grounds, some of these allegations include:
\end{abstract}

- Low status of Teachers 
- Low academic standards

- Unequal distribution of educational facilities among various sections of the society i.e. between male and female and urban and rural areas;

- More emphasis on liberal arts subjects as compared to scientific and technical programs

Keeping in view of these factors, Educational Policy of 1972 recommended the nationalization of private schools and a complete ban was imposed on the establishment of new schools in the private sector. After a period of seven years, the educational policy of 1979 again recommended the establishment of new schools in the private sector. At present, a large number of institutions from primary to university level are working in this country in the private sector.

Key words: Private sector, School education, Academic standard, Educational policy

\section{Introduction}

The purpose of this paper is to provide historical descriptive analysis of various procedural trends and developments that emerged in Pakistan for private sector school education. The purpose, here is, to understand the past in order to avoid the repetition of mistakes in the future. In this paper, an attempt has been made to review and examine the National Education plans, policies and existing provisions, which have been adopted to expand private sector role in the system of school level education in Pakistan.

The emergence of private sector in the development of education in Pakistan dated back to British period. The British ruled over the United India (present Pakistan and India) for two centuries. Pakistan is a newly established state; it got independence on $14^{\text {th }}$ August, 1947. At the time of independence the country was in a pitiable condition. The resources were scarce, political system was in doldrums, economy was at havoc and the education system was not so established. The literacy rate was very low. In spite of all these challenges the political leadership was highly motivated. The founder of the nation, Mr. Muhammad Ali Jinnah was a visionary person. He wanted to see his country at par with any developed country of the world. He realized the importance of education. In the first Educational Conference that was held in 1947, he showed his willingness and commitment for the development of education in the country.

The system of education in Pakistan is categorized as elementary (Class I to VIII), secondary and higher secondary (class IX to XII) and university level. The country's education sector has been classified broadly into three parallel systems i.e. public or government run schools, private schools and madrasas (religious schools). Each of which follows its own curriculum, teaching methods and examination and assessment system.

The role of private sector in the development of school education has remained significant. The overall share of this sector in total enrolment is around 36\%, its enrolment $42 \%$ in pre-primary education, primary stage $13 \%$, middle stage $58 \%$ high $45 \%$ and higher secondary $34 \%$ ( National Education Policy, 2009). How private sector contributed in the development of school education in Pakistan? To what extent government has provided its support to sustain the sector 
and how this sector played its role for raising the quality of school education in Pakistan? These fundamental questions would guide us in our inquiry.

\subsection{Methodology}

In this paper the followings approaches has been employed for data collection:

- Analyzing national educational policies and plans;

- reviewing current and past literature;

- Sharing personal experiences of the researchers;

\section{Historical Development of the Private System of Education in Pakistan}

The development of education in Pakistan may be divided into three periods:

Period I: Pre-Independence Period (Before 1947)

Period II: Onward Political Developments (1947 to onwards)

Period III: From 1979 to onwards

The British took over the responsibility of providing education to India in 1935. The basic purpose was to create a class of people well-versed in British thought and tradition, loyal to the government and fit for medium level jobs in the law and order establishment. In this system the medium of instruction was English language and the curriculum was based on Macaulay's Scheme of diffusion of European literature and sciences among the masses of India. When Lord Macaulay, The British Educational Commissioner in United India, prepared his final report in 1835, he mentioned the objective of education as, " our object of education in India is not to educate the masses but to create such groups which could disseminate the acquired knowledge to others.'(Cited in Qaisrani, 1984)

In 1854, the Wood Dispatch report recommended more participation of government in the development of education system. It gave the concept of teacher training and suggested about the administration, management and supervision of education. It laid down the grants - in- aid system. It also recommended the provision of education for women. The discussion of the subject closed with the following remarks:

We look forward to the time when any government system of education entirely provided by the government may be discontinued, with gradual advance of grants - in- aid and those of higher order may be safely closed or transferred to management of local bodies, under the control of and aided by the state(Ibid,p.381, Cited in Qaisrani, 1984)

The 'Indian Education Commission' was the other important event in the history of education. The main recommendations of this report were emphasis on primary education, more facilities to backward areas and girls' education. It also recommended the delegation of responsibilities to local bodies, municipalities and district boards. In addition, it emphasized more participation of the private sector.

Though the British Education System was secular in nature, it did have certain good things which continue to benefit the India and Pakistan. It introduced the concept of equality of opportunities, introduction of English language, scientific method and knowledge. Qaisrani (1984) while tracing the origin of private education in Pakistan stated that in pre-partition days, religious bodies, welfare organizations and philanthropic people took great interest in providing educational facilities to the masses. In the pre-partition days these agencies came 
forward with a reaction to secular education provided by the British administration. He further highlighted this factor, as, "In the 1920s and 1930s, the concept of separate Muslim and Hindu nationalism were developed in Indian Politics. One of the consequences of this change was that both communities took interest in the establishment of private schools. These are the main reasons that before 1947, the larger numbers of primary schools were in the private sector, while government owned a very small share. Hussain (2001) stated that "It is quite obvious that private sector was playing a very active role in providing the educational facilities to a vast number of students." The following table presents the distribution of educational institutions in United India for the period 1946-47:

Table I

Management of School Education in United India for the period 1946-47

\begin{tabular}{|l|l|l|l|}
\hline School Category & Private sector & Local Bodies & Government \\
\hline Primary Schools & $42.64 \%$ & $53.23 \%$ & $4.50 \%$ \\
\hline Middle Schools & $47.09 \%$ & $50.24 \%$ & $2.65 \%$ \\
\hline High Schools & $82.73 \%$ & $8.09 \%$ & 9.18 \\
\hline
\end{tabular}

(Source: Quraishi, 1962)

The data indicated that in pre-partition times $42.64 \%$ of the total primary schools were in the private sector. This tradition did not continue after the creation of Pakistan in 1947. The share of private middle schools and high schools were greater. The private sector existed, but it shifted its activities towards higher education. It was noted that majority of private schools did exist in major cities of Pakistan.

Table II

Local Bodies School in Selected cities of Pakistan, 1967

\begin{tabular}{|l|l|l|l|}
\hline School Location & Private sector & Local Bodies & Government \\
\hline Rawalpindi & $36.93 \%$ & $39.65 \%$ & $23.41 \%$ \\
\hline Lahore & $42.51 \%$ & $28.28 \%$ & $29.20 \%$ \\
\hline Hyderabad & $30.98 \%$ & $33.33 \%$ & $35.68 \%$ \\
\hline
\end{tabular}

(Source: Qaisrani, 1984)

The table showed that private sector flourished in the big cities where people could afford and schools collected tuition fee. During the year 1967-68, the private sector was very much active in big cities of Pakistan. The following table would help us to understand the situation:

Table III

Location of Privately Managed Institutions in Pakistan

\begin{tabular}{|l|c|}
\hline \multicolumn{1}{|c|}{ Region } & Percentage of Private School \\
\hline \multicolumn{1}{|c|}{ Lahore } & $42.51 \%$ \\
\hline Rawalpindi & $40 \%$ \\
\hline Hyderabad & $31 \%$ \\
\hline Karachi & $73.38 \%$ \\
\hline Quetta & $22 \%$ \\
\hline Pakistan & $40.2 \%$ \\
\hline
\end{tabular}


It was clear that private sector schools were located in the big cities of Pakistan. As the above table indicated that the biggest city Karachi had $73.38 \%$ of private schools, where majority of population was rich. The rural areas of Pakistan did not have private schools.

\section{Nationalization of Educational Institutions}

One of the important events in the history of Pakistan was the Nationalization of all private Schools. In 1972, the Government of Pakistan nationalized all private schools. The study conducted by the World Bank mentioned that the Government nationalized a total of 3334 educational institutions. Some private schools were exempted from Nationalization. These included some religious and elite schools.

Before nationalization the private sector was fully involved in the promotion school education. Hussain (2000) mentioned that "before 1972, much of the country's secondary and higher secondary education was in hands of private sector. Although exact figures are relatively scarce. In 1968, over half of all students in higher education were enrolled in private sector.

Regarding the reasons of privatization, the Government was of the view that these private institutions were not providing quality education. The Commission on Students Problems and Welfare 1966 (cited in Qaisrani, 1984) observed:

The position in most of the private schools and colleges, other than those run by Christian Missionary societies, is much worse. The teachers are poorly paid. They have no service condition, no security of service and incentives for good work... these institutions run on commercial basis within eye on earning profits.

Hussain (2000) explained that the main aim behind this privatization was to provide equal opportunities of education to all children irrespective of their parent economic background. In the Educational Policy 1972-80 it was stated that:

"Privately- managed schools will be nationalized in a phased manner. No compensation shall be payable to any person because of his being divested of any privately managed college or privately managed schools or of any property attached thereto. No person who owns or manages privately managed college or schools such close such schools or in any manner alienate, sell otherwise transfer any property attached thereto."

This Nationalization annoyed the owners of private institutions, some institutions which were running satisfactorily, also nationalized. The government took a very abrupt decision in making nationalizing schools. As a result of nationalization, no doubt, employees, (teachers and staff working in these schools) were provided job security, pay protection and other fringe benefits but there was rare accountability among employees. Teachers and employees unions heightened pressure on government for the fulfillments of their illegal demands. The situation further became depressing when government appointed, posted and promoted teachers on political basis. This resulted in deterioration of educational standards in government run schools. The Education Policy of 1979 again recommended the establishment of educational institutions in the private sector. This policy gave new birth to private institutions.

The National Educational Policy1998-2010 elaborated that the private sector virtually disappears from education as a result of nationalization in 1972. It re-appread in 1979 as a result of an amendment in the nationalization enactment. The government has recently establishes Educational Foundations for providing financial assistance to the private sector for 
opening non-commercial institutions in the country. This policy also suggested matching grants for private sector as well as tax rebate.

The National Educational Policy 2009 also appraised the role of private sector of education. The policy states that the private sector contributes about $0.5 \%$ of the GDP to education. It further explains about the new role of this sector, policy says that private sector role has been expanding in recent in recent years. Due to negligence of public sector, private sector is being promoted in the country.

\subsection{Re-emergence of Private Education Sector: Some Fears and Concerns}

As a result of 1979 Education Policy, the private sector again organized and became important partner in the delivery of education. The civil society reacted differently on the role of this sector. One group of people warmly welcomed this sector, while other group of people had different opinions about this sector. Andrabi (2000) mentions that private sector contributed significantly in the education of Pakistan. He was of the opinion that this sector did well both in terms of numbers of schools as well as proportion of children enrolled.

There were some issues raised regarding the quality of education being imparted at private schools. As Memon (2007) observed that the quality of education being imparted by the majority of private schools is questionable due to an acute shortage of properly trained and qualified teachers and any kind of support mechanism for these teachers. Except for large school systems like Beaconhouse, City, Lahore Grammar Schools, which constitute a small percentage of the existing private schools, majority of others have appointed teachers who are under qualified upto Intermediate (12 grade of schooling). Hussain (2000) also observed that some people have different views about the private sector. These people view that private sector serves the upper class and this sector encourage class system. Khan (2005) indicated that private teachers are poorly paid and fee in general is much higher than the government schools. The researchers personally observed many private schools. Majority of these schools are established in houses or in bungalows. Children have very few opportunities for sports and games. Physically children look exhausted and lazy. Very little has been done for their social and physical development. Moreover, it has been seen that majority of institutions in private sector emphasized on humanities subjects rather than scientific and technical subjects.

No doubt, private sector is doing a good job in improving education in Pakistan. Our purpose, here is, not to underestimate this sector, but to provide policy makers certain concrete suggestions that help them to revitalize the role of this sector.

\section{Findings}

- Private sector did play an important role in the development of school education before the inception of Pakistan (i.e. 1947) and this sector was also remained active till 1972(Before the Nationalization of Schools).

- The Private sector concentrated its efforts in urban areas of Pakistan. Very few schools were established in the rural areas of Pakistan, where majority of population live. The 
analysis indicated that, most of the time, the elite class benefited from private institution because they easily paid the tuition fee.

- The education policies and plans (From 1947-1971) advocated the role of private sector. The Education Policy of 1972 had not any soft corner for private sector. It nationalized all private institutions.

- The nationalization of private institutions irritated private owners but on the other hand, it brought good news for teachers and employees because they got permanent employment and better service conditions.

- Growth rates of education in Pakistan, after nationalization, went down, but the distribution of education improved. As the education was free.

- The Private sector, again, re-emerged in Pakistan in 1979. It gave new birth to private sector of education.

- The new education policies strongly advocate the establishment of private institutions.

\section{Suggestions}

- Local Bodies have the potential to contribute in the development of education in urban areas. Therefore, district governments may be encouraged to sponsor education in their area of jurisdiction.

- Special incentives may be given to NGOs and private sector to establish female schools in rural areas of Pakistan.

- Private sector may be encouraged to establish technical and vocational education. They may be provided soft loans in this regard.

- Rules of regulation (for opening private school) and affiliation must be observed and strictly followed.

- Private sector should offer salary and other benefits at par with teachers working in government system.

- Government should encourage and support private sector in indentifying and opening 'ghost schools' (a term used in Pakistan for schools that were established on paper or schools were teachers do not come regularly but enjoy salary). We further suggest, government should transfer these schools to private sector and use these schools for improving education of rural areas.

\section{Conclusion}

Private sector is playing a key role in the development of school education. The national educational policies and plans advocated the establishment of private institutions in the country.

Pakistan is still struggling in achieving the targets of EFA and Millennium Development Goals (MDGs). About $50 \%$ of the population is illiterate. The participation rate at primary and secondary level in rural areas of Pakistan is not satisfactory. Government alone cannot solve the problems of education of this country because of limited resources. Involvement of private sector not only improves education of children but will also generate a new culture of public 
private partnership. This will help both government and private management in improving the quality of education.

\section{References}

Andrabi, T., Das, J. \& Khawaja, A.(2000). The rise of private schooling in Pakistan: Catering to the urban elite or educating the rural poor. Retrieved on September, 22, 2008 from tandrabi@pomona.edu

Commission on Students problems and Welfare (1966). Karachi: Ministry of Education.

Hussain, M. (2000) Private sector and policy planning in Pakistan. Journal of Elementary Education, 10(2), Lahore: University of Punjab.

Hussain, M. (2001). Role of Private Sector in Education of Pakistan: An Historical Overview. Journal of Education, 15(1), Islamabad: Allama Iqbal Open University.

Khan, S., R. (2005). Basic Education in Rural Pakistan. A comparative institutional analysis of government, private and NGO schools .Karachi: Oxford University Press.

Memon, G., R. (2007). Education in Pakistan: The Key issues, problems, and the new challenges. Journal of Management and Social Sciences, 3(1), pp. 47-55, Retrieved on January 11, 2011 from http://www.international.ac.uk/resources/Education\%20in\%20Pakistan\%20\%20The\%20Key\%20Issues, \%20Problems\%20and\%20The\%20New\%20Challenges.pdf.

Government of Pakistan (1998). National Educational Policy 1998-2010. Islamabad: Ministry of Education.

Government of Pakistan (2009). National Educational Policy 2009. Islamabad: Ministry of Education.

Qaisrani, N., M. (1984). A comparative analysis of two sets of educational policies and their impact on educational development in Pakistan. Unpublished doctoral dissertation submitted to University of Michigan. Michigan: USA.

Quraishi, S., M. (1962). Private agencies in education In Mukerji (ed). Administration of education in India. Baroda: India.

World Bank. (1996). Improving Basic Education in Pakistan. 